\title{
О ПОЛЬЗОВАНИИ СЛОВАРЕМ
}

1. У существительных приводиться курсивом указание рода ( $m=$ мужской род, $f=$ женский род, $n=$ средний род). Существительные приводятся в именительном падеже единственного числа. Если существительные употребляются исключительно или преимущественно во множественном числе, то указывается именительный падеж множественного числа $(p l)$ :
Schwerspatgang $m$ бари́товая жи́ла
Springflut $f$ сизиги́йный прили́в
Sulfiderz $n$ сульфйдная руда́
Trockenfilter $m, n$ сухо́й фильтр
Rubiales $p l$ мареноцве́тные
Ubertagearbeiten $f / p l$ назе́мные рабо́ты

2. В случае необходимости приводятся дополнительные пояснения - синонимы, формулы, краткие пояснения, название видов животных и растений (курсив). Специальные области указываются при помощи соответствующих сокращений $(\mathrm{Pal} .=$ палеонтология, Bohr. = буровая техника, Inggeol. $=$ инженерная геология и т. д.) или существительных.

Kratersee $m$ Maаr кра́терное б́зеро

Krausit $m \mathrm{KFe}^{\cdots} \cdot\left[\mathrm{SO}_{1}\right]_{2} \cdot \mathrm{H}_{2} \mathrm{O}$ краузи́ч

Kysehtymit $m$ kristallines Gestein aus dem Ural кыштыми́т

Löwe $m$ Felis leo $L$. лев

schncll bindend Beton быстросхва́тывающий

3. Устаревшие названия минералов обозначаются $\dagger$ :

Leopoldit $m$ † Sylvin леопольди́т

Leucophyllit $m \dagger$ Sericit лейкофилли́т

4. После слова или дополнительных пояснений к нему приводятся русские әквиваленты. Синонимы или оттенки значений разделяются запятой, различные значения обозначаются цифрами и отделяются друг от друга точками :

Lauf $m$ 1. Flußlauf тече́ние, пото́к. 2. Verlauf бег, ход. 3. Bahn (Gestirn) движе́ние, путь

leitend 1. führend руководя́щий. 2. elektrisch leitend проводи́мый

Lösung $f$ 1. Chem. раствóp, растворе́ние. 2. Ergebnis реше́ние, разреше́ние

5. Глаголы, как правило, приводятся в инфинитиве. У русских әквивалентов указывается вид, причём, в видовых парах слева от косой черты стоящий 
XII

глагол имеет значение несовершенного вида, справа стоящий глагол - совершенного вида. Двувидовые глаголы обозначаются укаванием $u v,, v$. Причастия со специальным значением приводятся как самостоятельные слова:

absetzen, sich 1. abstehen отста́иваться/отстоя́ться. 2. ablagern, sich осажда́ться $u v$.

begehbar проходи́мый

generalisieren обобща́ть/обобщи́ть, генерализи́ровать $u v ., v$.

gesehichtet слои́стый, напласто́ванный

loten измеря́ть/изме́рить ло́том (глубину) 